\title{
Radiation interception, extinction coefficient and use efficiency of wheat crop at various irrigation and nitrogen levels in a semi- arid location
}

\author{
S. Pradhan ${ }^{1,2} \cdot$ V. K. Sehgal ${ }^{2}$ K. K. Bandyopadhyay ${ }^{2}$ - P. Panigrahi ${ }^{1}$. \\ C. M. Parihar ${ }^{2}$ S. L. Jat ${ }^{3}$
}

Received: 23 October 2016/ Accepted: 17 September 2018/Published online: 29 September 2018

(C) The Author(s) 2018

\begin{abstract}
Field experiments were conducted to study the effect of irrigation and nitrogen levels on radiation use efficiency (RUE), radiation extinction coefficient $(\kappa)$ and temporal variation of leaf area index (LAI) and fraction intercepted photosynthetically active radiation (fIPAR). The LAI of wheat increased with increase in irrigation and nitrogen levels. The fIPAR also followed trend similar to LAI. The LAI and fIPAR showed logarithmic relationship with $\mathrm{R}^{2}$ value of 0.92 and 0.93 for the years 2013-2014 and 2014-2015, respectively. The $\kappa$ value varied between 0.41 and 0.78 and was significantly affected by nitrogen levels but was not influenced by irrigation levels. The grain and above ground biomass (AGB) yields of wheat were not affected significantly by irrigation levels. However, application of $160 \mathrm{~kg} \mathrm{~N} \mathrm{ha}^{-1}(\mathrm{~N} 160)$ registered higher grain $(12-33 \%)$ and AGB (22-25\%) yeilds as compared to that with application of $40 \mathrm{~kg} \mathrm{~N} \mathrm{ha}^{-1}$ (N40). Similar to AGB, the total intercepted photosynthetically active radiation (TIPAR) was not affected by irrigation levels but N160 treatment registered 9-20\% higher TIPAR compared to N40 treatment. The linear relationship between TIPAR and AGB revealed that $83-86 \%$ variation in AGB yield of wheat can be explained by TIfIPAR. The RUE of wheat under three irrigations (I3) was 6 and $18 \%$ higher $(P<0.05)$ than the five (I5) and two (I2) irrigation
\end{abstract}

S. Pradhan

sanatan28@gmail.com

1 ICAR-Indian Institute of Water Management, Bhubaneswar, Odisha 751 023, India

2 ICAR-Indian Agricultural Research Institute, New Delhi, Delhi 110 012, India

3 ICAR-Indian Institute of Maize Research, New Delhi, Delhi 110 012, India treatments, respectively for the year 2013-2014. However, there was no significant effect of irrigation on RUE of wheat in the year 2014-2015. N160 treatment registered 5-13\% higher RUE than the N40 treatment. Thus wheat may be grown with three irrigations (CRI, flowering and grain filling) and $160 \mathrm{~kg} \mathrm{~N} \mathrm{ha}^{-1}$ for higher RUE without significant reduction in AGB of wheat compared to five irrigation levels in semi-arid location of Delhi region.

Keywords Radiation interception - Radiation extinction coefficient · RUE · Wheat

\section{Introduction}

Wheat is the second most important cereal crop of India covering an area of 30 million ha with a production of 94 million tons in the year 2012-2013. Water and fertilizer (nitrogen) are the two most important inputs, which greatly contribute to wheat productivity more specifically in the arid and semi-arid tract of India where wheat is grown as a dry season crop (Pradhan et al. 2014d). Traditionally, crop responses to irrigation and nitrogen levels have been reported by many workers (Bandyopadhyay et al. 2010; Pradhan et al. 2014a, b, d; Ranjan et al. 2015) but there are very few studies evaluating the integrated effect of irrigation and nitrogen supply on the ecophysiological determinants of above ground biomass (AGB) production of wheat.

The AGB production of crop is directly related to the amount of intercepted photosynthetically active radiation (IPAR) by the crop canopy during its life cycle (Monteith 1977; Abbate et al. 1997; Sandaña et al. 2009; Pradhan et al. 2014d). The AGB per unit of total IPAR is called as radiation use efficiency (RUE) (Sinclair and Muchow 
1999). The RUE of cereals is constant in non-stressful environments (Gallagher and Biscoe 1978; Sinclair and Muchow 1999). Therefore, AGB produced can be expressed as a product of the cumulative IPAR during the crop growth cycle and RUE (Sandaña et al. 2009). This approach is commonly employed in radiation use efficiency based crop growth models (Ritchie and Otter 1985; Jones et al. 1991; Keating et al. 1997; Brisson et al. 2003; Stöckle et al. 2003; Aggarwal et al. 2004) and remote sensing estimation of biomass (Casanova et al. 1998). The cumulative total IPAR of crops is mostly controlled by fraction of the incoming photosynthetically active radiation by the canopy, which is a function of green leaf area index (LAI) and the efficiency with which the green leaf area intercepts solar radiation, described by the light extinction coefficient ( $\kappa$ ) (Plénet et al. 2000; Muurinen and PeltonenSainio 2006; Massignam et al. 2009; Sandaña et al. 2009). Several studies have shown that total IPAR is negatively related to both water and nitrogen deficiencies in wheat (Pradhan et al. 2014d; Dreccer et al. 2000; Salvagiotti and Miralles 2008). The $\kappa$ values for wheat varies between 0.37 and 0.82 (Yunusa et al. 1993; O'Connell et al. 2004; Muurinen and Peltonen-Sainio 2006). Thomas (2013) observed that effect of irrigation was not significant on $\kappa$ of wheat in a semi-arid location of India. Similar to irrigation, many authors have reported that nitrogen did not effect $\kappa$ significantly (Green 1987; Muurinen and Peltonen-Sainio 2006). Though there are studies on the effect of irrigation and nitrogen on total IPAR and light extinction coefficient in isolation, studies on interactive effect of irrigation and nitrogen on these parameters are limited.

Besides species and cutivars, RUE is mostly affected by the management factors such as water and nitrogen application (Sinclair and Muchow 1999; Stöckle and Kemanian 2009; Muurinen and Peltonen-Sainio 2006). Under nonstressed conditions, the RUE values of wheat varies from 1.46 to 2.93 (Gregory et al. 1992; Yunusa et al. 1993). Water stress reduces RUE by reducing the utilization of photosynthates for growth as lower intercepted phtosynthetically active radiation occurs from reduced LAI (Wilson and Jamieson 1985; O'Connell et al. 2004). Negative responses of RUE to water stress has been presented by many workers for wheat (Han et al. 2008; Li et al. 2008; Thomas 2013). RUE is also affected by the nutrient application (Sinclair and Horie 1989; Plénet et al. 2000) and among all the nutrients, nitrogen influences RUE the most (Muurinen and Peltonen-Sainio 2006). RUE reduction under lower nitrogen application conditions is related to lower specific leaf nitrogen content and RUE increases linearly with nitrogen application till the specific leaf nitrogen stays under saturating $\mathrm{N}$ content (Sinclair and Muchow 1999). The negative effect of nitrogen application to RUE of wheat is well documented (Pradhan et al. 2014d;
Muurinen and Peltonen-Sainio 2006). However, similar to IPAR and $\kappa$, the study on interactive effect of irrigation and nitrogen on RUE is also limited.

Successful modeling of plant growth and remote sensing estimation of biomass relies on accurate description of LAI, light extinction coefficient for IPAR and RUE. Keeping these in view, the objectives of this study were to determine the interactive effect of irrigation and nitrogen on (a) temporal variation in LAI and fraction IPAR and, (b) total IPAR, grain and AGB yield, $\kappa$ and RUE of wheat in a semi-arid location of India.

\section{Materials and methods}

\section{Study area and experimental details}

Field experiments were conducted during dry season (winter) of 2013-2014 and 2014-2015 at the experimental farm of the Indian Agricultural Research Institute (IARI), New Delhi $\left(77^{\circ} 89^{\prime} \mathrm{E}\right.$ Longitude, $28^{\circ} 37^{\prime} \mathrm{N}$ Latitude and $228.7 \mathrm{~m}$ above mean sea level), with wheat (Triticum aestivum L.) as test crop. The area comes under semi-arid subtropical climatic belt. The texture of the study site was sandy loam (Typic Haplustept), low in organic carbon and available nitrogen and medium in available $\mathrm{P}$ and $\mathrm{K}$ content. The bulk density varied from 1.56 to $1.74 \mathrm{Mg} \mathrm{m}^{-3}$, saturated hydraulic conductivity from 0.49 to $1.02 \mathrm{~cm} \mathrm{~h}^{-1}$ and saturated water content from 0.38 to $0.42 \mathrm{~m}^{3} \mathrm{~m}^{-3}$ in the upper $0-1.20 \mathrm{~m}$ soil layer. The soil moisture content varied between 26-29\% at $0.33 \mathrm{MPa}$ (field capacity) and $8-11 \%$ at $1.5 \mathrm{MPa}$ (permanent wilting point) in different layers of $0-1.20 \mathrm{~m}$ soil depth.

The experiment was laid out in a split-plot design with irrigation levels as main plot treatments and nitrogen levels as sub-plot treatments, replicated three times. The subplot size was $5 \times 5 \mathrm{~m}^{2}$. The irrigation levels were I2: two irrigations (CRI and flowering stages), I3: three irrigations (CRI, flowering and grain filling stages) and I5: five irrigations (CRI, tillering, Jointing, flowering and grain filling stages). In each irrigation, an amount of $60 \mathrm{~mm}$ water was applied through surface irrigation. The irrigation amount was measured by Parshall Flume. The amount of irrigation water applied for I2, I3 and I5 were 60, 120, and 240 and 120, 120 and $240 \mathrm{~mm}$ for the years 2013-2014 and 2014-2015, respectively. The nitrogen levels were N40: $40 \mathrm{~kg} \mathrm{~N} \mathrm{ha}^{-1}$ and N160: $160 \mathrm{~kg} \mathrm{~N}^{-1}$. The source of nitrogen fertilizer was urea. Nitrogen was applied in three splits (Basal: $50 \% \mathrm{~N}$; CRI: $25 \% \mathrm{~N}$ and flowering stage: $25 \% \mathrm{~N})$. All the plots received recommended basal dose of phosphorous and potassium $\left(60 \mathrm{~kg} \mathrm{P}_{2} \mathrm{O}_{5} \mathrm{ha}^{-1}\right.$ as single super phosphate and $60 \mathrm{~kg} \mathrm{~K}_{2} \mathrm{O} \mathrm{ha}^{-1}$ as muriate of potash). Wheat crop (cv. HD 2967) was sown on 26th and 18th 
November in the years 2013 and 2014, respectively, by a tractor drawn seed drill (at a depth of $4-5 \mathrm{~cm}$ ) with a row spacing of $22.5 \mathrm{~cm}$ and seed rate of $100 \mathrm{~kg} \mathrm{ha}^{-1}$. The crop was harvested on 15th and 20th April in 2013 and 2014, respectively.

\section{Leaf area index (LAI)}

Leaf area index was measured at regular intervals using a plant canopy analyzer (LAI-2000, LI-COR, Lincoln, NE, USA). The timing of LAI observation coincided with the timing of observation for photosynthetically active radiation (PAR).

\section{Canopy radiation extinction coefficient (к)}

Both incoming and outgoing photosynthetically active radiation (PAR) values were measured periodically at the top and bottom of the wheat canopy throughout the season using line quantum sensor LI-191SA (LICOR Inc., Lincoln, NE, USA). The fraction intercepted PAR (fIPAR) was calculated as (Monteith 1981):

$f I P A R=\frac{I o-I}{I}$

where Io is incident PAR at the top of canopy and I is the transmitted PAR at the bottom of the canopy.

The canopy fIPAR and LAI were related by the relationship given below (Monsi and Saeki 1953):

$f I P A R=1-e^{(-\kappa \times L A I)}$

where, $\kappa$ is the canopy radiation extinction coefficient and LAI is the leaf area index. The $\kappa$ was determined with least-square regression by calculating the slope of the relationship between $\ln (1$ - fIPAR) and LAI (Robertson et al. 2001) with intercept set to zero.

\section{Yield}

The net plot $(5 \mathrm{~m} \times 5 \mathrm{~m})$ was harvested manually by cutting the plants close to ground after leaving the border rows. The plant samples were dried and weighed for AGB yield and expressed in $\mathrm{kg} \mathrm{ha}^{-1}$. Threshing of wheat was done mechanically and the grain yield was expressed in $\mathrm{kg} \mathrm{ha}^{-1}$.

\section{Radiation use efficiency (RUE)}

Values for fIPAR for each day after sowing were interpolated between actual measurements by linear interpolation throughout the crop season (Pradhan et al. 2014c, d; Saha et al. 2015). Daily incoming solar radiation was calculated by using bright sunshine hours in the Angstrom equation (Allen et al. 1998). The daily incoming solar radiation was multiplied by a factor 0.48 (Monteith 1972) to get incoming incident PAR. Then the daily incident PAR values were multiplied by corresponding daily fIPAR values to compute daily intercepted PAR (IPAR). The daily IPAR was integrated for the whole crop season to get total IPAR (TIPAR). The RUE was calculated by dividing total AGB $\left(\mathrm{g} \mathrm{m}^{-2}\right)$ with the TIPAR $\left(\mathrm{MJ} \mathrm{m}^{-2}\right)$ for the whole crop duration (Pradhan et al. 2014c, d).

\section{Statistical analysis}

The data were statistically analyzed using analysis of variance (ANOVA) as applicable to split-plot design (Gomez and Gomez 1984). F test was employed to see the significance of the treatment effects. The difference between the means was estimated using least significance difference and Duncan's multiple range tests at 5\% probability level. Regression analyses were performed using the data analysis tool pack of MS Excel (2007).

\section{Results and discussion}

\section{Weather}

Mean monthly temperature, relative humidity, solar radiation, rainfall and reference evaporation (Allen et al. 1998) are presented in Table 1 . The mean monthly temperature was almost similar in both the years of study except for the month of February. The mean monthly temperature of February 2014-2015 was $3.1^{\circ} \mathrm{C}$ higher than that of the year 2013-2014. It coincides with the flowering and milk stage of wheat crop growth. The wheat crop growth period of 2014-2015 (315.8 $\mathrm{mm})$ received significantly higher rainfall than the year 2013-2014 (169.2 mm). More specifically, March month of 2014-2015 received $201.8 \mathrm{~mm}$ rainfall compared to $63.5 \mathrm{~mm}$ of the year 2013-2014. However, the February month of 2013-2014 received $63.5 \mathrm{~mm}$ rainfall in four spells whereas the year 2014-2015 did not receive any rainfall for the same period. The mean monthly relative humidity was almost similar for both the years of study except for the month of February. The February month of the year 2013-2014 registered 10\% higher relative humidity compared to the year 2014-2015. It could be attributed to the higher February rainfall of the year 2013-2014 compared to the year 2014-2015. The solar radiation received for the study period of the year 2014-2015 (2617 $\mathrm{MJ} \mathrm{m}^{-2}$ ) was almost similar to the year 2013-2014 (2639 $\left.\mathrm{MJ} \mathrm{m}^{-2}\right)$. Similarly, the reference evapo-transpiration for the study period of 2014-2015 $(523 \mathrm{~mm})$ and 2013-2014 (512 $\mathrm{mm})$ were almost similar. The higher reference evapo-transpiration for the month of 
Table 1 Weather condition during the period of study

\begin{tabular}{|c|c|c|c|c|c|c|c|c|c|c|}
\hline \multirow[t]{2}{*}{ Months } & \multicolumn{2}{|c|}{ Mean temperature $\left({ }^{\circ} \mathrm{C}\right)$} & \multicolumn{2}{|c|}{$\begin{array}{l}\text { Mean relative humidity } \\
\left({ }^{\circ} \mathrm{C}\right)\end{array}$} & \multicolumn{2}{|c|}{$\begin{array}{l}\text { Total solar radiation } \\
\left(\mathrm{MJ} \mathrm{m}^{-2}\right)\end{array}$} & \multicolumn{2}{|c|}{ Total rainfall (mm) } & \multicolumn{2}{|c|}{$\begin{array}{l}\text { Total reference } \\
\text { evapotranspiration }(\mathrm{mm})\end{array}$} \\
\hline & 2013-2014 & 2014-2015 & 2013-2014 & 2014-2015 & 2013-2014 & 2014-2015 & 2013-2014 & 2014-2015 & 2013-2014 & 2014-2015 \\
\hline Nov & 18.4 & 19.5 & 70 & 61 & 368 & 392 & 0.4 & 0 & 69 & 77 \\
\hline Dec & 14.7 & 13.7 & 75 & 76 & 325 & 333 & 6.8 & 26.4 & 52 & 53 \\
\hline Jan & 12.7 & 11.9 & 82 & 83 & 289 & 290 & 18.6 & 35.8 & 46 & 45 \\
\hline Feb & 14.5 & 17.6 & 80 & 70 & 373 & 394 & 63.5 & 0 & 59 & 75 \\
\hline Mar & 20.0 & 20.2 & 69 & 71 & 564 & 585 & 63.5 & 201.8 & 114 & 116 \\
\hline Apr & 26.3 & 26.5 & 57 & 60 & 698 & 645 & 16.4 & 51.8 & 172 & 157 \\
\hline
\end{tabular}

February 2014-2015 (75 $\mathrm{mm})$ compared to the year 2013-2014 (59 mm) may be attributed to the higher solar radiation received during the same period corresponding to the previous period. On the whole, wheat crop of the year 2013-2014 experienced more congenial weather compared to the wheat crop of the year 2014-2015.

\section{Leaf area index (LAI)}

The temporal variation in LAI of wheat crop for irrigation and nitrogen treatments of both the years of study are presented in Figs. 1 and 2. The LAI value increased steadily till 83-98 days after sowing and then declined. The
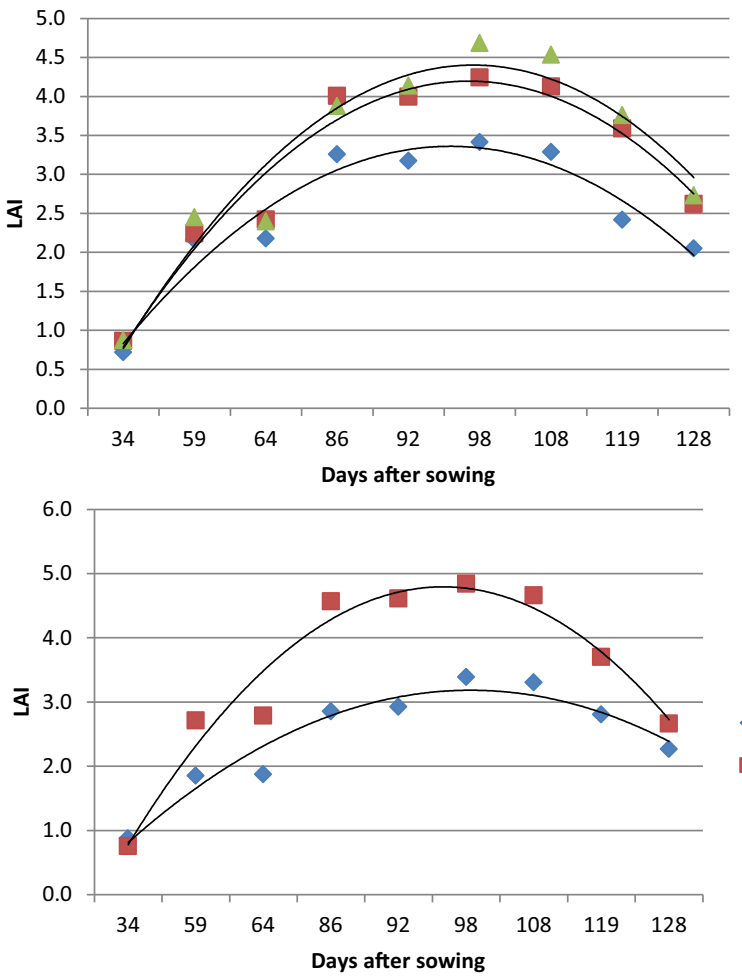

b

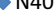

N160

Fig. 1 LAI variation of wheat 2013-2014 at different days after sowing (DAS) for irrigation (a) and nitrogen (b) treatments
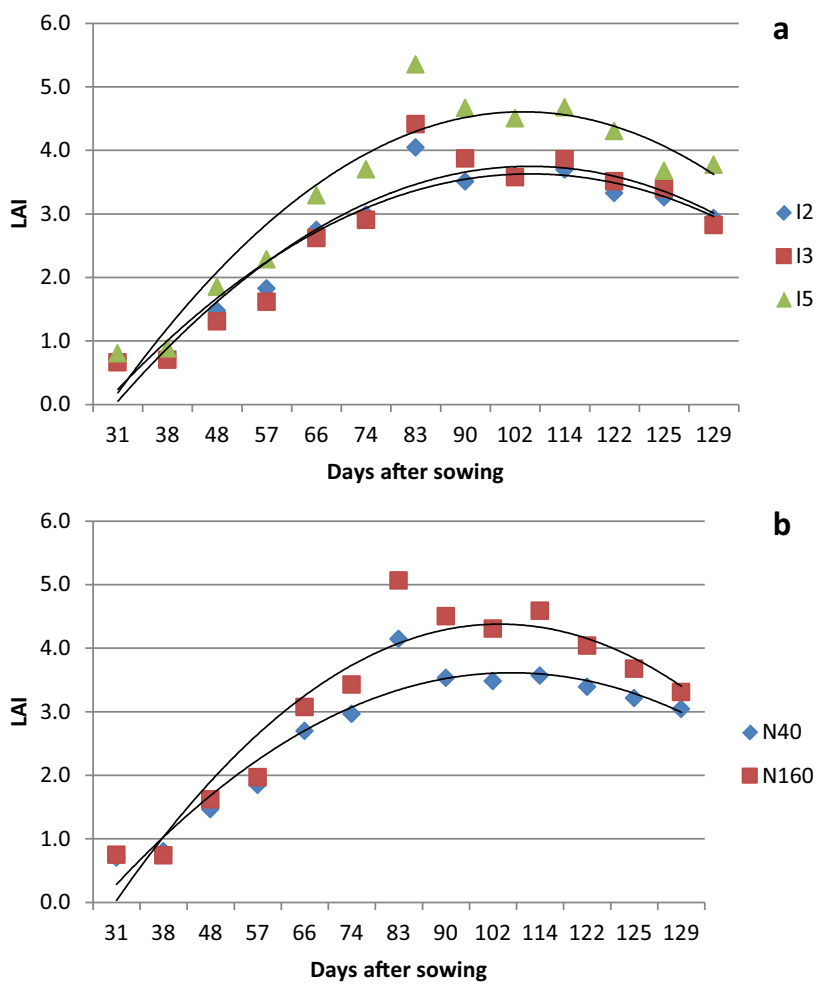

Fig. 2 LAI variation of wheat 2014-2015 at different days after sowing (DAS) for irrigation (a) and nitrogen (b) treatments

increase in LAI may be attributed to foliage expansion because of development of new leaves and enlargement of existing leaves (Mandal et al. 2005). The peak value of LAI in the present experiment coincided with the booting to flowering stage of wheat. This finding is in agreement with Akram (2011) and Bassu et al. (2011) for wheat. The decrease in LAI during later part of crop growth is ascribed to leaf senescence (Thomas 2013; Mandal et al. 2005; Pradhan et al. 2013; Bandyopadhyay et al. 2010). Averaged over nitrogen treatments, the highest LAI for I5, I3 and I2 treatments were 4.69, 4.24 and 3.42 in 2013-2014 and $5.35,4.41$ and 4.05 in 2014-2015, respectively. In the year 2013-2014, the effect of irrigation levels were significant 
$(P<0.05)$ only on LAI measured at 128 days after sowing. However, in the year 2014-2015, irrigation effects were significant $(P<0.05)$ on LAI measured at 83, 90, 122 and 129 days after sowing. In both the years of study, the LAI of reproductive stage of wheat was highest in I5 followed by I3 and I2. Increased water stress due to differential level of irrigation application might have led to increased abscission rate and hence decreased in LAI (Akram 2011; Thomas 2013). Averaged over irrigation levels, the highest LAI for N40 and N160 treatments were 3.39 and 4.84 in 2013-2014 and 4.14 and 5.06 in 2014-2015, respectively. Nitrogen treatment significantly $(P<0.05)$ affected LAI of wheat at all stages of measurement except at 34 days after sowing for the year 2013-2014. However, in the second year, the significant effect of nitrogen levels on LAI were observed only at 83, 90, 102, 114 and 122 days after sowing. Higher LAI with increased $\mathrm{N}$ application could be attributed to significant increases in leaf expansion (length and breadth) resulting from cell division and cell enlargement at higher $\mathrm{N}$ rates. Similar results were reported by Wright (1982) and Kar and Kumar (2015) for maize, and Shafi et al. (2011) for barley. The interaction effect of irrigation and nitrogen on LAI was not significant for both the years of study.

\section{Fraction intercepted PAR (fIPAR)}

The temporal variation of fIPAR of wheat for irrigation and nitrogen treatments of both the years are presented in Fig. 3 and 4 . The fIPAR increased continuously till 98 DAS in 2013-2014 and 102 DAS in 2014-2015 and then decreased with progress of season. Pradhan et al. (2014c) also reported curvilinear relationship between fIPAR and days after sowing for wheat. The temporal variation of fIPAR followed the trend similar to that of LAI. Jha et al. (2012) and Serrano et al. (2000) have also observed that temporal variation in fIPAR showed the trend similar to LAI for mustard and wheat, respectively. The graphical relationship between LAI and fIPAR for both the years of study are presented in Fig. 5. The LAI and fIPAR showed logarithmic relationship with $\mathrm{R}^{2}$ value of 0.92 for 2013-2014 and 0.93 for 2014-2015. In both the years, fIPAR increased with increase in LAI, initially at higher rate and then at lower rate and finally flattening. This could be ascribed to the lower rate of change of fIPAR to higher rate of change of LAI after achieving the peaks of fIPAR and LAI, respectively (Thomas 2013). The irrigation levels did not affect fIPAR significantly throughout the crop growth period of 2013-2014 and 2014-2015 (Fig. 3a and 4a). Averaged over nitrogen treatments, the highest fIPAR (\%) for I5, I3 and I2 treatments were $85.5,90.2$ and $91.3 \%$ in 2013-2014 and 91.3, 92.3 and $96.2 \%$ in 2014-2015, respectively. However, the nitrogen levels significantly
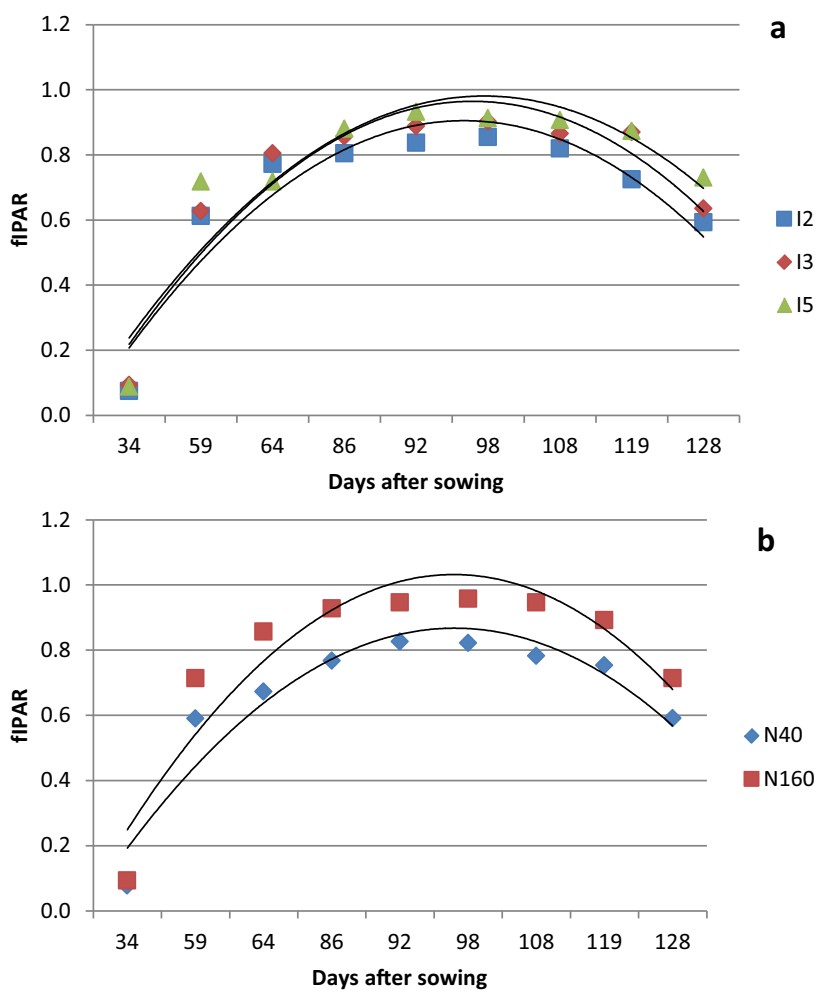

Fig. 3 fIPAR variation of wheat 2013-2014 at different days after sowing (DAS) for irrigation (a) and nitrogen (b) treatments
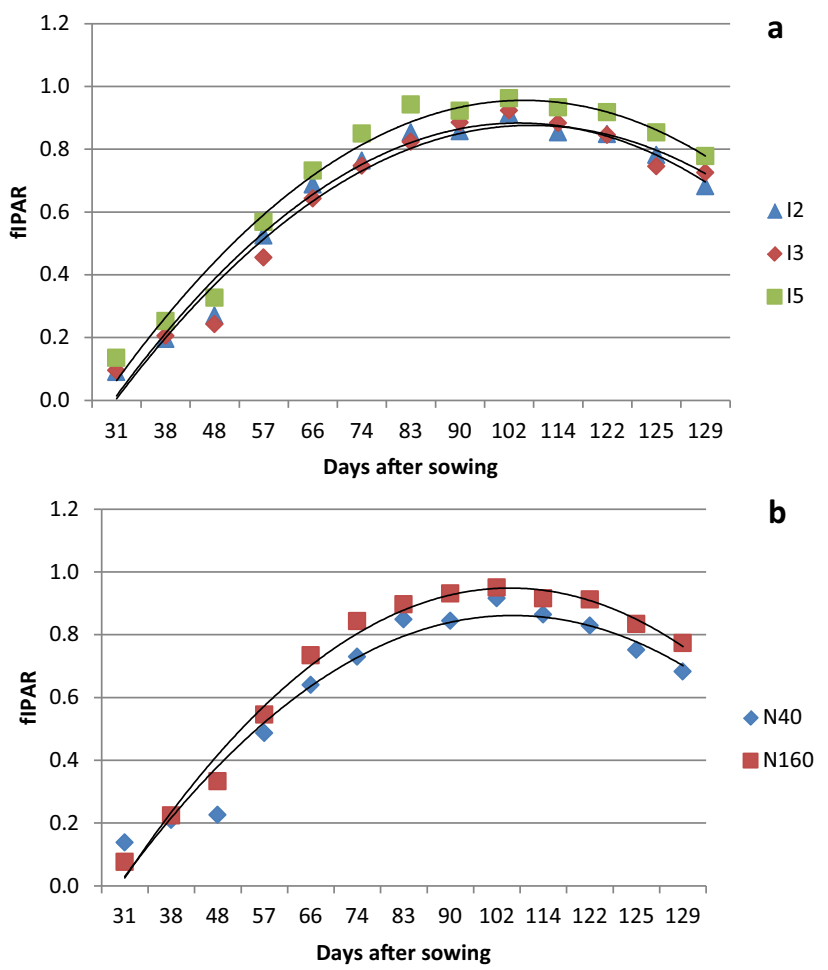

Fig. 4 fIPAR variation of wheat 2014-2015 at different days after sowing (DAS) for irrigation (a) and nitrogen (b) treatments 

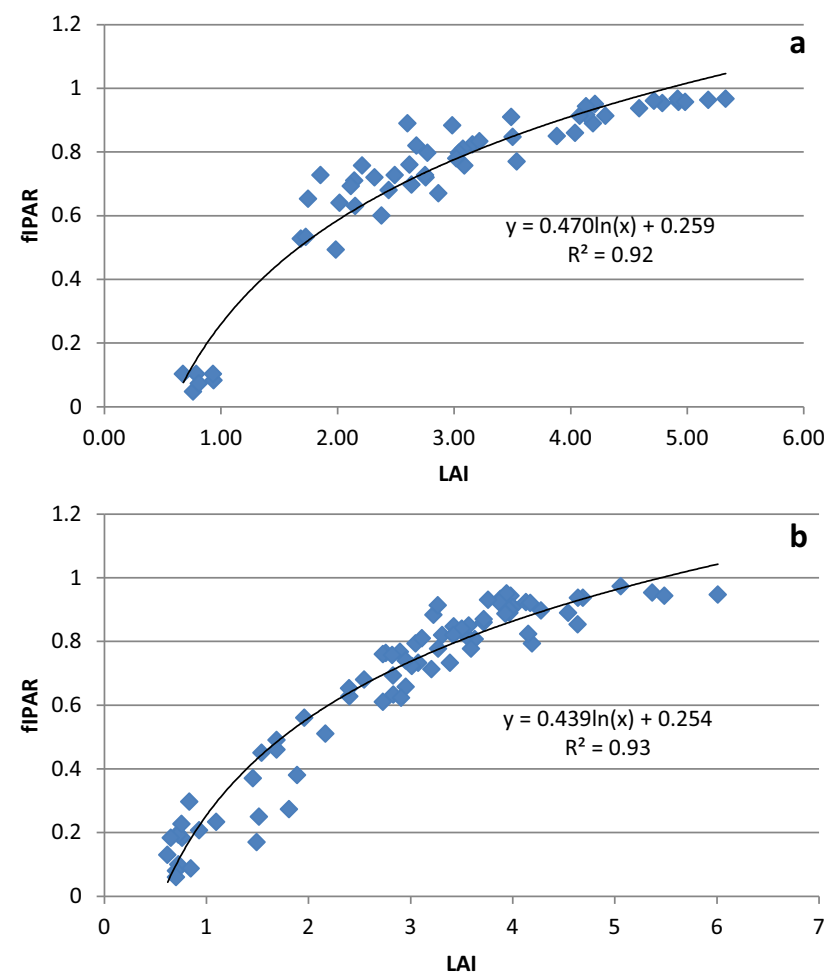

Fig. 5 LAI and fIPAR relationship for 2013-2014 (a) and 2014-2015 (b)

(13-21\% in 2013-2014 and 4-32\% in 2014-2015) affected fIPAR at almost all stages of its measurement (Figs. $3 \mathrm{~b}$ and 4b). Averaged over irrigation treatments, the highest fIPAR (\%) for N160 and N40 treatments were 82.2 and $95.8 \%$ in 2013-2014 and 91.6 and $95.0 \%$ in 2014-2015, respectively. The lower fIPAR in N40 treatments compared to N160 treatments can be attributed to lower LAI in the former than the later. Bassu et al. (2011) has also observed lower fIPAR in durum wheat due to lower LAI. The interaction effect of irrigation and nitrogen were not significant on fIPAR for both the years of study.

\section{Light extinction coefficient (к)}

The canopy light extinction coefficient [the slope of $\ln (1$ - fIPAR $)$ and LAI relationship] was obtained for each treatment and subjected to statistical analysis and presented in Figs. 6 and 7. The $\kappa$ varied between 0.51 (I2N40) to 0.65 (I3N160) in 2013-2014 and 0.47 (I2N40) to 0.58 (I2N160) in 2014-2015 (data not presented). The estimated $\kappa$ values fall within the range of 0.41 and 0.78 reported for bread wheat (Yunusa et al. 1993; O'Connell et al. 2004; Muurinen and Peltonen-Sainio 2006). The irrigation levels had no significant effect on $\kappa$ for both the years of study (Fig. 6a). This result is in agreement with the Thomas (2013). However, $\kappa$ was significantly $(P<0.05)$ lower in $\mathrm{N} 40$ (16\% in 2013-2014 and $9 \%$ in 2014-2015) compared to

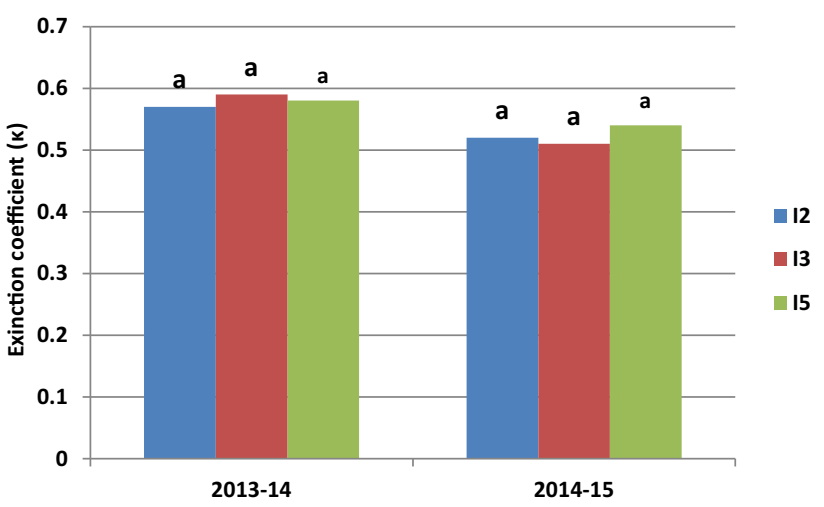

Fig. 6 Extinction coefficient $(\kappa)$ of wheat at different irrigation levels for 2013-2014 and 2014-2015. Columns marked by same letters are not significantly different at $P<0.05$ in a year

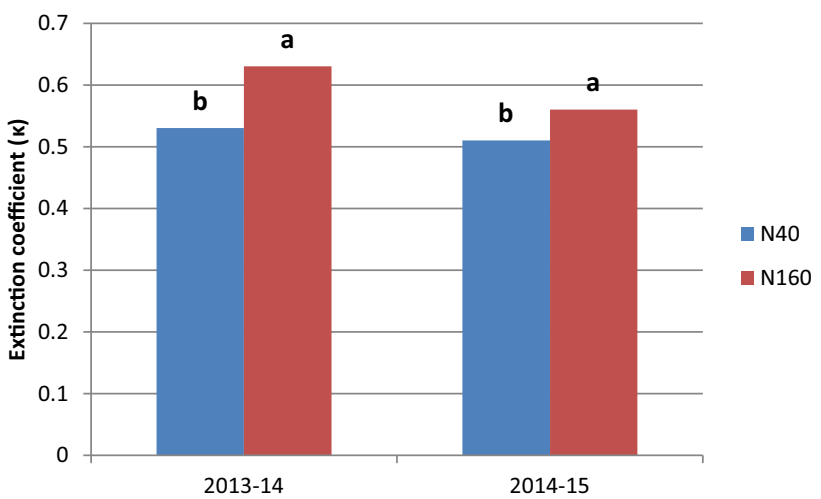

Fig. 7 Extinction coefficient ( $\kappa)$ of wheat at different nitrogen levels for 2013-2014 and 2014-2015. Columns marked by same letters are not significantly different at $P<0.05$ in a year

N160. It indicated that under nitrogen stress condition, the leaf becomes more erect resulting in better penetration of PAR into the canopy and hence lower fIPAR and RUE (Kiniry et al. 1989; Brekke et al. 2011; Bassu et al. 2011; Saha et al. 2015).

\section{Yield}

The grain and above ground biomass (AGB) yields are presented in Table 2. The grain yield varied between 2750 (I2N40) and 5500 (I5N160) $\mathrm{kg} \mathrm{ha}^{-1}$ with an average value of $4340 \mathrm{~kg} \mathrm{ha}^{-1}$ for 2013-2014 and 3285 (I2N40) to 4001 (I5N160) $\mathrm{kg} \mathrm{ha}^{-1}$ with an average value of $3732 \mathrm{~kg} \mathrm{ha}^{-1}$ for 2014-2015. Similar to grain yield, the AGB varied between 8125 (I2N40) and 14,500 (I5N160) $\mathrm{kg} \mathrm{ha}^{-1}$ with an average value of $11,833 \mathrm{~kg} \mathrm{ha}^{-1}$ for 2013-2014 and 8625 (I2N40) to 13,500 (I5N160) $\mathrm{kg} \mathrm{ha}^{-1}$ with an average value of $10,993 \mathrm{~kg} \mathrm{ha}^{-1}$ for 2014-2015. The mean grain yield was $14 \%$ lower in 2014-2015 as compared to 2013-2014. However, the mean AGB yield was 7\% lower in 2014-2015 as compared to 2013-2014. The decrease in 
Table 2 Above ground biomass $\left(\mathrm{kg} \mathrm{ha}^{-1}\right)$, TIPAR $\left(\mathrm{MJ} \mathrm{m}^{-2}\right)$ and RUE $\left(\mathrm{g} \mathrm{MJ}^{-1}\right)$ of wheat for different irrigation and nitrogen levels

\begin{tabular}{|c|c|c|c|c|c|c|c|c|}
\hline & \multicolumn{2}{|c|}{ Grain yield $\left(\mathrm{kg} \mathrm{ha}^{-1}\right)$} & \multicolumn{2}{|c|}{ Above ground biomass $\left(\mathrm{kg} \mathrm{ha}^{-1}\right)$} & \multicolumn{2}{|c|}{ TIPAR $\left(\mathrm{MJ} \mathrm{m}^{-2}\right)$} & \multicolumn{2}{|c|}{$\operatorname{RUE}\left(\mathrm{g} \mathrm{MJ}^{-1}\right)$} \\
\hline & 2013-2014 & 2014-2015 & 2013-2014 & 2014-2015 & 2013-2014 & $2014-2015$ & 2013-2014 & 2014-2015 \\
\hline \multicolumn{9}{|c|}{ Effect of irrigation } \\
\hline $\mathrm{I} 2$ & $3417 \mathrm{a}$ & $3603 a$ & $9729 a$ & $9646 a$ & $422 \mathrm{a}$ & $474 b$ & $2.29 \mathrm{c}$ & $2.03 \mathrm{a}$ \\
\hline I3 & $4833 a$ & $3719 a$ & $12729 a$ & $10917 \mathrm{a}$ & $469 \mathrm{a}$ & $489 b$ & $2.70 \mathrm{a}$ & $2.22 \mathrm{a}$ \\
\hline I5 & $4771 \mathrm{a}$ & $3875 a$ & $13042 a$ & $12417 \mathrm{a}$ & $509 \mathrm{a}$ & $555 \mathrm{a}$ & $2.55 b$ & $2.23 \mathrm{a}$ \\
\hline \multicolumn{9}{|c|}{ Effect of nitrogen } \\
\hline N40 & $3722 b$ & $3520 \mathrm{a}$ & $10500 \mathrm{~b}$ & $9903 b$ & $424 b$ & $485 b$ & $2.45 \mathrm{a}$ & $2.03 \mathrm{a}$ \\
\hline N160 & $4958 \mathrm{a}$ & $3944 a$ & $13167 \mathrm{a}$ & $12083 a$ & $509 a$ & $527 \mathrm{a}$ & $2.58 \mathrm{a}$ & $2.29 \mathrm{a}$ \\
\hline \multicolumn{9}{|c|}{ Effect of irrigation $\times$ nitrogen } \\
\hline I2 N40 & $2750 \mathrm{c}$ & $3285 a$ & $8125 \mathrm{c}$ & $8625 c$ & $367 \mathrm{c}$ & $440 \mathrm{c}$ & $1.97 \mathrm{a}$ & $2.21 \mathrm{a}$ \\
\hline I2 N160 & $4083 b c$ & $3920 \mathrm{a}$ & $11333 b$ & $10667 \mathrm{abc}$ & $477 \mathrm{ab}$ & $508 b$ & $2.10 \mathrm{a}$ & $2.37 \mathrm{a}$ \\
\hline I3 N40 & $4375 \mathrm{ab}$ & $3525 a$ & $11792 \mathrm{ab}$ & $9750 \mathrm{bc}$ & $425 b c$ & $480 \mathrm{bc}$ & $2.04 \mathrm{a}$ & $2.73 \mathrm{a}$ \\
\hline I3 N160 & $5292 \mathrm{ab}$ & $3913 a$ & $13667 \mathrm{ab}$ & $12083 \mathrm{ab}$ & $513 a$ & $499 \mathrm{bc}$ & $2.42 \mathrm{a}$ & $2.67 \mathrm{a}$ \\
\hline I5 N40 & $4042 \mathrm{bc}$ & $3749 a$ & $11583 \mathrm{ab}$ & $11333 \mathrm{abc}$ & $481 \mathrm{ab}$ & $536 \mathrm{ab}$ & $2.09 \mathrm{a}$ & $2.39 \mathrm{a}$ \\
\hline I5 N160 & $5500 \mathrm{a}$ & $4001 \mathrm{a}$ & $14500 \mathrm{a}$ & $13500 \mathrm{a}$ & $536 a$ & $574 a$ & $2.32 \mathrm{a}$ & $2.71 \mathrm{a}$ \\
\hline
\end{tabular}

yield of wheat in 2014-2015 compared to 2013-2014 can be attributed to the higher rainfall $(201.8 \mathrm{~mm})$ causing aeration stress during the March month of 2014-2015. Thomas (2013) has also reported decrease in yield of wheat due to aeration stress. The grain yield was not significantly $(P<0.05)$ affected by the irrigation levels for both the years of study. The N160 treatment registered 33\% higher $(P<0.05)$ grain yield compared to $\mathrm{N} 40$ treatment in 2013-2014. However, in 2014-2015 the N160 and N40 treatments were statistically at par. Similar to grain yield, the AGB was not significantly $(P<0.05)$ affected by irrigation levels for both the years of study (Table 2). However, the AGB of wheat was significantly affected by nitrogen levels. N160 treatment registered 25\% and 22\% higher AGB compared to N40 treatment during the years 2013-2014 and 2014-2015, respectively. The increased yield in N160 treatment compared to N40 treatment can be attributed to increased LAI (Figs. 1 and 2), green spikes area and crop duration with greenness, which resulted increased interception of radiation (Latiri-Souki et al. 1998; Pradhan et al. 2014d). The interaction effect of irrigation and nitrogen treatments was significant on the grain yield of 2013-2014 and AGB of both the years of study. The highest grain and AGB yield was observed in I5N160 and lowest in I2N40 treatment for both the year of study. The grain yield of I5N160, I3N160 and I3N40 were statistically at par. The I3N40, I3N160, I5N40 and I5N160 treatments in 2013-2014 and I2N160, I3N160, I5N40 and I5N160 treatments in 2014-2015 were statistically at par with respect to AGB.

\section{Total intercepted PAR (TIPAR)}

The total intercepted PAR (TIPAR) is one of the most important factors of crop production (Monteith 1981). In the present experiment, TIPAR varied between 367 (I2N40) and 536 (I5N160) $\mathrm{MJ} \mathrm{m}^{-2}$ with a mean value of $467 \mathrm{MJ} \mathrm{m}^{-2}$ in 2013-2014 and 440 (I2N40) to 574 (I5N160) $\mathrm{MJ} \mathrm{m}^{-2}$ with a mean value of $506 \mathrm{MJ} \mathrm{m}^{-2}$ for the year 2014-2015 (Table 2). The higher (8\%) TIPAR in 2014-2015 crop season compared to 2013-2014 crop season may be attributed to longer crop duration and better LAI in 2014-2015 than 2013-2014. The TIPAR was not significantly affected by irrigation levels in the first year (Table 2). However, in the second year, significantly higher TIPAR was observed in I5 (555 $\left.\mathrm{MJ} \mathrm{m}^{-2}\right)$ compared to I3 $\left(489 \mathrm{MJ} \mathrm{m}^{-2}\right)$ and $\mathrm{I} 2$ treatments $\left(474 \mathrm{MJ} \mathrm{m}^{-2}\right)$, and I3 and I treatments were statistically at par with respect to TIPAR. The nitrogen levels significantly $(P<0.05)$ affected TIPAR for both the years of study (Table 2). N160 registered higher TIPAR than the N40 treatments by $20 \%$ and 9\% for the year 2013-2014 and 2014-2015, respectively. The higher TIPAR at higher irrigation and nitrogen levels is attributed to higher LAI (Han et al. 2008; Bassu et al. 2011). The relationship between AGB and TIPAR of wheat at various irrigation and nitrogen treatments are presented in Fig. 8. These relationships are linear in nature. The TIPAR was significantly $(P<0.01)$ and positively correlated with the AGB yield of wheat $(\mathrm{r}=0.93 * *$ for the year 2013-2014 and 0.0.91** for the year 2014-2015). The linear relationship between TIPAR and AGB depicts 86 and $83 \%$ variation in AGB yield of wheat can be explained 


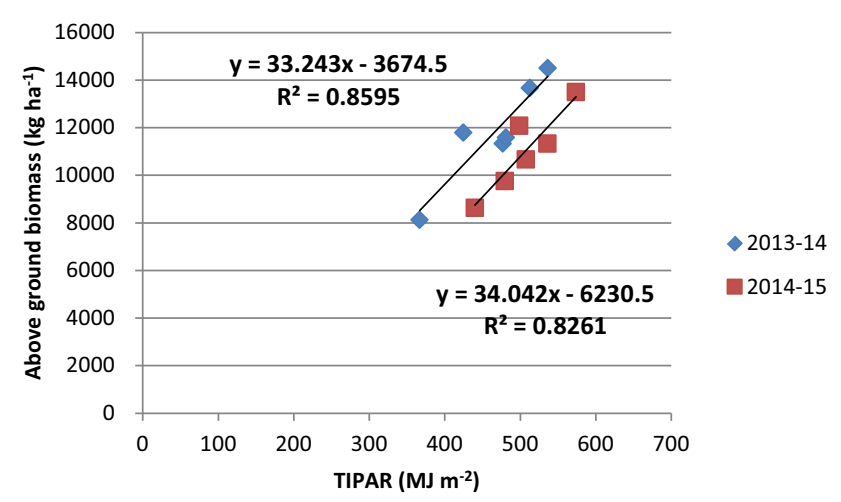

Fig. 8 TIPAR versus above ground biomass of wheat for the year 2013-2014 and 2014-2015

by TIPAR for the year 2013-2014 and 2014-2015, respectively. Similar relationship has been observed in many crops (pigeon pea, chickpea, mustard, wheat, soybean, maize) by various workers (Singer et al. 2011; Pradhan et al. 2014c, d; Saha et al. 2015; Kar and Kumar 2015).

\section{Radiation use efficiency (RUE)}

The radiation use efficiency (biomass produced per unit intercepted radiation) of wheat varied between 1.97 (I2N40) and 2.42 (I3N160) $\mathrm{g} \mathrm{MJ}^{-1}$ in 2013-2014 with an average value of $2.51 \mathrm{~g} \mathrm{MJ}^{-1}$ and 2.21 (I2N40) and 2.73 (I3N40) $\mathrm{g} \mathrm{MJ}^{-1}$ with an average value of $2.16 \mathrm{~g} \mathrm{MJ}^{-1}$ for the year 2014-2015 (Table 2). In the present experiment, our estimated RUE values were within the range of 1.20 and $2.93 \mathrm{~g} \mathrm{MJ}^{-1}$ reported in literature for wheat across a range of environments (Kiniry et al. 1989; Siddique et al. 1989; Gregory et al. 1992; Gregory and Eastham 1996). In 2013-2014, the significantly highest $(P<0.05)$ RUE was observed in I3 $\left(2.70 \mathrm{~g} \mathrm{MJ}^{-1}\right)$ followed by I5 $\left(2.55 \mathrm{~g} \mathrm{MJ}^{-1}\right)$ and $\mathrm{I} 2\left(2.29 \mathrm{~g} \mathrm{MJ}^{-1}\right)$. However, in 2014-2015, I5 (2.23 $\left.\mathrm{g} \mathrm{MJ}^{-1}\right)$, I3 $\left(2.22 \mathrm{~g} \mathrm{MJ}^{-1}\right)$ and I2 $\left(2.03 \mathrm{~g} \mathrm{MJ}^{-1}\right)$ irrigations levels were statistically at par $(P<0.05)$ with respect to RUE. However, even though RUE values were not significantly different among nitrogen levels (Table 2), they showed a decreasing trend (5\% in 2013-2014 and 13\% in 2014-2015) with decrease in $\mathrm{N}$ levels. It can be attributed to the lower AGB and higher root biomass in N40 which is commonly observed under stressful environments resulting lower RUE (Siddique et al. 1989; Hamblin et al. 1990; Jamieson et al. 1995). The decrease in RUE (based on AGB) among the treatments was mostly due to the variation in AGB than the variation in TIPAR. This is clear from the good correlation between the AGB of wheat with the RUE (0.84 for 2013-2014 and 0.88 for 2014-2015) than TIPAR with the RUE (0.57 for 2013-2014 and 0.61 for 2014-2015). However, the RUE showed good correlation (0.88) in 2013-2014 and poor correlation (0.47) in 2014-2015 with grain yield. The poor correlation between RUE and grain yield for 2014-2015 can be ascribed to the non-significant variation in grain yield among the treatments due to excess rainfall. These findings are in agreement with the findings of Whitfield and Smith (1989), Li et al. (2008) and Han et al. (2008) for wheat. The interaction effect of irrigation and nitrogen levels on RUE were not significant for both the years of study.

\section{Conclusion}

It was concluded that fIPAR of wheat followed a curvilinear relationship with time similar to that of leaf area index. There was increase in IIPAR and LAI with the increase in the irrigation level up to five irrigations and with the increase in nitrogen does up to $160 \mathrm{~kg} \mathrm{~N} \mathrm{ha}^{-1}$. There was no significant difference in the TIPAR among the irrigation treatments in high rainfall year but in normal rainfall years, TIPAR increased significantly up to five irrigation level. However in both the years TIPAR of wheat increased up to $160 \mathrm{~kg} \mathrm{~N}^{-1}$. There was no significant difference among the irrigation treatments with respect to extinction coefficient but it increase significantly due to increase in $\mathrm{N}$ dose up to $160 \mathrm{~kg} \mathrm{~N} \mathrm{ha}^{-1}$. During normal rainfall year 5 irrigation with $160 \mathrm{~kg} \mathrm{~N}^{-1}$ registered highest grain and biomass yield of wheat which is at par with 3 irrigations with $160 \mathrm{~kg} \mathrm{~N} \mathrm{ha}^{-1}$. However during high rainfall years though five irrigations with $160 \mathrm{~kg} \mathrm{~N}$ $\mathrm{ha}^{-1}$ registered highest biomass yield of wheat yet grain yield was not affected by irrigation and $\mathrm{N}$ levels. During normal rainfall years 3 irrigations registered highest RUE but in high rainfall years effect irrigation was not significant on RUE of wheat. So wheat may be grown with three irrigations at critical stages and $160 \mathrm{~kg} \mathrm{~N} \mathrm{ha}^{-1}$ in the semiarid region of Delhi region without any significant yield reduction compared to five irrigations and to achieve higher radiation use efficiency under normal rainfall situation.

Open Access This article is distributed under the terms of the Creative Commons Attribution 4.0 International License (http://crea tivecommons.org/licenses/by/4.0/), which permits unrestricted use, distribution, and reproduction in any medium, provided you give appropriate credit to the original author(s) and the source, provide a link to the Creative Commons license, and indicate if changes were made.

Funding Funding was provided by Indian Agricultural Research Institute, New Delhi, India. 


\section{References}

Abbate, P. E., Andrade, F. H., Culot, J. P., \& Bindraban, P. S. (1997). Grain yield in wheat: Effects of radiation during spike growth period. Field Crops Research, 54, 245-257.

Aggarwal, P. K., Kalra, N., Chander, S., \& Pathak, H. (2004). Infocrop-A generic simulation model for annual crops in tropical environment (p. 132). New Delhi: Indian Agricultural Research Institute.

Akram, M. (2011). Growth and yield components of wheat under water stress of different growth stages. Bangladesh Journal of Agricultural Research, 36, 455-468.

Allen, R. G., Pereira, L. S., Raes, D., \& Smith, M. (1998). Crop evapotranspiration-Guidelines for computing crop water requirements (Vol. 108, pp. 57-74). FAO irrigation and drainage paper, no. 56. FAO, Rome, ASCE.

Bandyopadhyay, K. K., Misra, A. K., Ghosh, P. K., \& Hati, K. M. (2010). Effect of integrated use of farmyard manure and chemical fertilizers on soil physical properties and productivity of soybean. Soil and Tillage research, 110, 115-125.

Bassu, S., Giunta, F., \& Motzo, R. (2011). Effects of sowing date and cultivar on radiation use efficiency in durum wheat. Crop and Pasture Science, 62, 39-47.

Brekke, B., Edwards, J., \& Knapp, A. (2011). Selection and adaptation to high plant density in the Iowa stiff stalk synthetic maize (Zea mays L.) population: II. Plant morphology. Crop Sciece, 51, 2344-2351.

Brisson, N., Gary, C., Justes, E., Roche, R., Mary, B., Ripoche, D., et al. (2003). An overview of the crop model STICS. European Journal of Agronomy, 18, 309-332.

Casanova, D., Epema, G. F., \& Goudriaan, J. (1998). Monitoring rice reflectance at field level for estimating biomass and LAI. Field Crops Research, 55, 83-92.

Dreccer, F., Schapendonk, A. H. C. M., Slafer, G. A., \& Rabbinge, R. (2000). Comparative response of wheat and oilseed rape to nitrogen supply: Absorption and utilization efficiency of radiation and nitrogen during the reproductive stages determining yield. Plant and Soil, 220, 189-205.

Gallagher, J. N., \& Biscoe, P. V. (1978). Radiation absorption, growth and yield of cereals. The Journal of Agricultural Science, 91, $47-60$.

Gomez, K. A., \& Gomez, A. A. (1984). Statistical procedures for agricultural research. New York: Willey.

Green, C. F. (1987). Nitrogen nutrition and wheat growth in relation to absorbed solar radiation. Agricultural and Forest Meteorology, 41, 207-248.

Gregory, P., \& Eastham, J. (1996). Growth of shoots and roots, and interception of radiation by wheat and lupin crops on a shallow, duplex soil in response to time of sowing. Australian Journal of Agricultural Research, 47, 427-447.

Gregory, P. J., Tennant, D., \& Belford, R. K. (1992). Root and shoot growth, and water and light use efficiency of barley and wheat crops grown on a shallow duplex soil in a Mediterranean-type environment. Australian Journal of Agricultural Research, 43, 555-573.

Hamblin, A., Tennant, D., \& Perry, M. W. (1990). The cost of stress: Dry matter partition-ing changes with seasonal supply of water and nitrogen to dryland wheat. Plant and Soil, 122, 47-58.

Han, H., Li, Z., Ning, T., Zhang, X., Shan, Y., \& Bai, M. (2008). Radiation use efficiency and yield of winter wheat under deficit irrigation in North China. Plant Soil and Environment, 54, 313-319.

Jamieson, P. D., Martin, R. J., Francis, G. S., \& Wilson, D. R. (1995). Drought effects on biomass production and radiation-use efficiency in barley. Field Crops Research, 43, 77-86.
Jha, S., Sehgal, V. K., \& Subbarao, Y. V. (2012). Effect of direction of sowing and crop phenotype on radiation interception, use efficiency, growth and productivity of Mustard (Brassica juncea L.). Journal of Agricultural Physics, 12, 37-43.

Jones, C. A., Dyke, P. T., Williams, J. R., Kiniry, J. R., Benson, C. A., \& Griggs, R. H. (1991). EPIC: An operational model for evaluation of agricultural sustainability. Agricultural Systems, 37, 341-350.

Kar, G., \& Kumar, A. (2015). Effects of phenology based irrigation scheduling and nitrogen on light interception, water productivity and energy balance of maize (Zea mays L.). Journal of the Indian Society of Soil Science, 63, 39-52.

Keating, B. A., Meinke, H., Probert, M. E., Huth, N. I., \& Hills, I. (1997). Nwheat: Documentation and performance of a wheat module for APSIM. Tropical Agriculture Technical Memo. CSIRO Division of Tropical Agriculture, St Lucia, QLD.

Kiniry, J. R., Jonnes, C. A., O’Toole, J. C., Blanchet, R., Cabelguenne, M., \& Spanel, D. A. (1989). Radiation use efficiency in biomass accumulation prior to grain filling for five grain crop spices. Field Crops Research, 20, 51-64.

Latiri-Souki, K., Nortcliff, S., \& Lawlor, D. W. (1998). Nitrogen fertilizer can increase dry-matter, grain production and radiation and water use efficiency for durum wheat under semi-arid conditions. European Journal of Agronomy, 9, 21-34.

Li, Q. Q., Chen, Y. H., Liu, M. Y., Zhou, X. B., Yu, S. L., \& Dong, B. D. (2008). Effects of irrigation and planting patterns on radiation use efficiency and yield of winter wheat in North China. Agricultural Water Management, 95, 469-476.

Mandal, K. G., Hati, K. M., Misra, A. K., Bandyopadhyay, K. K., \& Mohanty, M. (2005). Irrigation and nutrient effects on growth and water-yield relationship of wheat (Triticum aestivum L.) in Central India. Journal of Agronomy and Crop Science, 191, 416-425.

Massignam, A., Chapman, S., Hammer, G., \& Fukai, S. (2009). Physiological determinants of maize and sunflower grain yield as affected by nitrogen supply. Field Crops Research, 113, 256-267.

Monteith, J. L. (1972). Solar radiation and productivity in tropical ecosystems. Journal of Applied Ecology, 9, 747-766.

Monteith, J. L. (1977). Climate and the efficiency of crop production in Britain. Philosophical Transactions of the Royal Society B, 281, 277-294.

Monteith, J. L. (1981). Climatic variations and growth of crops. Quaterly Journal of the Royal Meteorological Society, 107, 749-774.

Muurinen, S., \& Peltonen-Sainio, P. (2006). Radiation use efficiency of modern and old spring cereal cultivars and its response to nitrogen in northern growing conditions. Field Crops Research, 96, 363-373.

Monsi, M., \& Saeki, T. (1953). Über den Lichtfaktor in den Pflanzengesellschaften und seine Bedeutung für die Stoffproduktion. Japanese Journal of Botany, 14, 22-52.

O'Connell, M. G., O'Leary, G. J., Whitfield, D. M., \& Connor, D. J. (2004). Interception of photosynthetically active radiation and radiation-use efficiency of wheat, filed pea and mustard in a semi-arid enviromnment. Field Crops Research, 85, 111-124.

Plénet, D., Mollier, A., \& Pellerin, S. (2000). Growth analysis of maize field crops under phosphorus deficiency. II. Radiation-use efficiency, biomass accumulation and yield components. Plant and Soil, 224, 259-272.

Pradhan, S., Bandyopadhyay, K. K., Sahoo, R. N., Sehgal, V. K., Singh, R., Gupta, V. K., et al. (2014a). Predicting wheat grain and biomass yield using canopy reflectance of booting stage. Journal of Indian Society of Remote Sensing, 42, 711-718.

Pradhan, S., Chopra, U. K., Bandyopadhyay, K. K., Krishnan, P., Singh, R., \& Jain, A. K. (2013). Soil water dynamics, root 
growth and water and nitrogen use efficiency of rain-fed maize (Zea mays) in a semi arid environment. Indian Journal of Agricultural Sciences, 83, 542-548.

Pradhan, S., Chopra, U. K., Bandyopadhyay, K. K., Singh, R., Jain, A. K., \& Chand, I. (2014b). Effect of deficit irrigation and nitrogen levels on water productivity and nitrogen use efficiency of wheat (Triticum aestivum) in a semi-arid environment. Indian Journal of Agricultural Sciences, 84, 887-891.

Pradhan, S., Sehgal, V. K., Das, D. K., Jain, A. K., Bandyopadhyay, K. K., Singh, R., et al. (2014c). Effect of weather on seed yield and radiation and water use efficiency of mustard cultivars in a semi-arid environment. Agricultural Water Management, 139, $43-52$.

Pradhan, S., Sehgal, V. K., Sahoo, R. N., Bandyopadhyay, K. K., \& Singh, R. (2014d). Yield, water, radiation and nitrogen use efficiencies of wheat (Triticum aestivum L.) as influenced by nitrogen levels in a semi-arid environment. Indian Journal of Agronomy, 59, 267-275.

Ranjan, R., Chopra, U. K., Sahoo, R. N., Pramanik, M., Singh, A. K., Pradhan, S., et al. (2015). Resource conservation in wheat (Triticum aestivum L.) under different water and nitrogen stress levels. Indian Journal of Soil Conservation, 43, 159-165.

Ritchie, J. T., \& Otter, S. (1985). Description and performance of CERES-Wheat: A user-oriented wheat yield model. USDA-ARS. ARS-38 (pp. 159-175).

Robertson, M. J., Slim, S., Chauhan, Y. S., \& Ranganathan, R. (2001). Predicting growth and development of pigeon pea, biomass accumulation and partitioning. Field Crops Research, 70, 89-100.

Saha, S., Sehgal, V. K., Chakraborty, D., \& Pal, M. (2015). Atmospheric carbon dioxide enrichment induced modifications in canopy radiation utilization, growth and yield of chickpea [Cicer arietinum L.)]. Agricultural and Forest Meteorology, 202, $102-111$.

Salvagiotti, F., \& Miralles, D. (2008). Radiation interception, biomass production and grain yield as affected by the interaction of nitrogen and sulfur fertilization in wheat. European Journal of Agronomy, 28, 282-290.

Sandaña, P., Harcha, C. I., \& Calderini, D. F. (2009). Sensitivity of yield and grain nitrogen concentration of wheat, lupin and pea to source reduction during grain filling. A comparative survey under high yielding conditions. Field Crops Research, 114, 233-243.

Serrano, L., Filella, I., \& Penuelas, J. (2000). Remote sensing of biomass and yield of winter wheat under different nitrogen supplies. Crop Science, 40, 723-731.
Shafi, M., Bakht, J., Khan, M. A., \& Khattak, S. G. (2011). Effects of nitrogen application on yield and yield components of barley (Hordenum vulgare L.). Pakistan Journal of Botany, 43, 1471-1475.

Singer, J. W., Meek, D. W., Sauer, T. J., Prueger, J. H., \& Hatfield, J. L. (2011). Variability of light interception and radiation use efficiency in maize and soybean. Field Crop Research, 121, $147-152$

Siddique, K. H. M., Belford, R. K., Perry, M. W., \& Tennant, D. (1989). Growth, development and light interception of old and modern wheat cultivars in a Mediterranean-type environment. Australian Journal of Agricultural Sciences, 40, 473-487.

Sinclair, T. R., \& Horie, T. (1989). Leaf nitrogen, photosynthesis, and crop radiation use efficiency: A review. Crop Science, 29, 90-98.

Sinclair, T. R., \& Muchow, R. C. (1999). Radiation use efficiency. Advances in Agronomy, 65, 215-265.

Stöckle, C. O., Donatelli, M., \& Nelson, R. (2003). CropSyst, a cropping systems simulation model. European Journal of Agronomy, 18, 289-307.

Stöckle, C., \& Kemanian, A. (2009). Crop radiation capture and use efficiency: A framework for crop growth analysis. In V. O. Sadras \& D. F. Calderini (Eds.), Crop physiology: Applications for genetic improvement and agronomy (pp. 145-170). San Diego, CA: Academic Press.

Thomas, P. (2013). Enhancing water productivity in wheat by optimization of irrigation management using AquaCrop model. M.Sc. thesis in agricultural physics. P.G. School IARI, New Delhi, India.

Whitfield, D. M., \& Smith, C. J. (1989). Effects of irrigation and nitrogen on growth, light interception and efficiency of light conversion in wheat. Field Crops Researcgh, 20, 279-295.

Wilson, D. R., \& Jamieson, P. D. (1985). Models of growth and water use of wheat in New Zealand. In W. Day \& R. K. Atkin (Eds.), Wheat growth and modelling (pp. 211-216). London: Plenum Press.

Wright, J. L. (1982). New evapotranspiration crop coefficients. Journal of Irrigation and Drainage Division, ASCE, 108, 57-74.

Yunusa, I. A. M., Siddique, K. H. M., Belford, R. K., \& Karimi, M. M. (1993). Effect of canopy structure on efficiency of radiation interception and use in spring wheat cultivars during the preanthesis period in a Mediterranean-type environment. Field Crops Research, 35, 113-122. 